\title{
The amino acid composition of human milk corrected for amino acid digestibility
}

\author{
Alison J. Darragh* and Paul J. Moughan \\ Milk and Health Research Centre, Institute of Food, Nutrition and Human Health, \\ Massey University, Palmerston North, New Zealand
}

(Received 22 July 1997 - Revised 28 November 1997 - Accepted 22 December 1997)

\begin{abstract}
Human milk was collected from women in their 10th-14th weeks of lactation, and was analysed for amino acids. Corrections were made for losses of amino acids which were presumed to occur during acid hydrolysis, using a non-linear mathematical model that describes the simultaneous processes of amino acid yield and decay. The mean amino acid composition of the human milk was found to be similar to previously reported estimates, although the cysteine content of the human milk in the present study was $20 \%$ higher than the average literature estimate. True (corrected for endogenous amino acid excretions) ileal amino acid digestibility of human milk was determined using the 3-week-old piglet as a model animal for the human infant. The piglets were given either human milk $(n 6)$ or a protein-free diet $(n 6)$ for a $6 \mathrm{~d}$ experimental period. $\mathrm{Cr}_{2} \mathrm{O}_{3}$ was added as an indigestible marker, to both the human milk and protein-free diet. At the end of the experimental period the piglets were anaesthetized and samples of digesta removed from the terminal ileum of each piglet. After sampling the piglets were killed. Endogenous ileal excretions of amino acids were determined in piglets fed on the protein-free diet. The true digestibilities of total $\mathrm{N}$ and amino acid $\mathrm{N}$ were $88 \%$ and $95 \%$ respectively. The true ileal digestibility of the non-amino acid $\mathrm{N}$ fraction in human milk, when calculated by difference was only $50 \%$. The true digestibility of the amino acids in human milk ranged from $81-101 \%$ with threonine $(86 \%)$ being the least digestible essential amino acid. When the true ileal digestibility values were used to correct the amino acid composition of human milk, the pattern of digestible amino acids in human milk was different compared with the currently recommended pattern of amino acid requirements for the infant.
\end{abstract}

Human milk: Amino acids: Digestion: Animal model: Piglet

There are several approaches for estimating the protein requirements of infants, and although there has been some debate as to its validity (Dewey et al. 1996), the amino acid composition of human milk is commonly used as the standard upon which to base the amino acid requirements of infants (Committee on Nutrition, 1985; Food and Agriculture Organization/World Health Organization/United Nations University (FAO/WHO/UNU), 1985, 1990). If the amino acid composition of human milk is to be used in this manner, however, there are two potential inaccuracies with present estimates of the profile of amino acids in human milk that need to be addressed. First, corrections for losses of amino acids which occur during the acid hydrolysis of milk samples before amino acid analysis, if made at all, are usually limited to serine and threonine. It has been demonstrated (Robel \& Crane, 1972) that for improved accuracy corrections for other amino acids are also necessary. Second, it is assumed that the amino acids in human milk are completely digested. This may not be correct. There are a number of proteins present in human milk, the nutritional roles of which are uncertain. Lactoferrin and secretory immunoglobulin A (IgA), comprising approximately $20 \%$ and $10 \%$ of the total protein in human milk respectively (van Woelderen, 1987), are involved in immune protection of the gastrointestinal tract (Lönnerdal, 1985). Significant amounts of these proteins have been identified in the faeces of breast-fed infants (Ogra et al. 1977; Davidson \& Lönnerdal, 1987; Prentice et al. 1989). Although secretory IgA and lactoferrin, presumably of endogenous origin, have also been identified in the faeces of formula-fed infants (Haneberg \& Tonder, 1973; Spik et al. 1982), the considerably higher amounts found in the faeces of breast-fed infants would suggest that secretory IgA and lactoferrin partially survive proteolysis in the gut. This has direct nutritional implications, in that the gross amino acid composition of human milk may not necessarily reflect the profile of amino acids available to the infant.

Estimates of the digestible protein in human milk, based 
on amounts of immune proteins detected in the breastfed infant's faeces, range from $70 \%$ of the total protein (Hambraeus et al. 1984) to 90-95\% of total protein (Davidson \& Lönnerdal, 1987). However, there is considerable microbial degradation of protein in the large intestine (McNeil, 1988) and amino acids do not appear to be absorbed in human colonic tissue (McNeil, 1988). Thus faecal estimates of digestibility may be misleading and digestibility may be better determined at the terminal ileum (Sauer \& Ozimek, 1986).

The aim of the present study was to determine the profile of amino acids absorbed in mature human milk. The study was conducted in two parts. The first part involved the collection of representative human milk samples and determination of the amino acid composition of each sample. Corrections were made for the losses of amino acids that occur during hydrolysis in acid before amino acid analysis, using a non-linear mathematical model (Darragh, 1995; Darragh et al. 1996). In part two of the study the 3-weekold piglet was used as an animal model for the human infant, to determine the true (corrected for endogenous amino acids) ileal digestibility of the amino acids in mature human milk. The true ileal digestible amino acid composition of human milk is compared with the recommended amino acid requirements of the infant (FAO/WHO/UNU, 1985).

\section{Part 1: Determination of the amino acid composition of mature human milk}

\section{Materials and methods}

All aspects of the human research reported in this part of the study were approved by the Massey University Human Ethics Committee.

Collection of milk samples. Twenty women (average age 29.6 (SE 0.83) years; mean body weight 64.7 (SE 2.08) $\mathrm{kg}$; sixteen were primiparous) whose pregnancies were uncomplicated, resulting in the vaginal delivery of fullterm infants and who were currently nursing healthy exclusively breast-fed infants, participated in the study. At the beginning of the collection period the women were in their 10th-14th weeks of lactation (average 12 (SE 0.3) weeks). The women were fully informed of the milk collection procedure.

The women participating in the study expressed samples of milk under supervision. The breast, from which milk had not been removed for at least 3-4h, and nipple were washed with distilled water and thoroughly dried with a sterile cotton towel. The maximum amount of milk that could be comfortably expressed (mean volume 83.9 (SE 6.0) $\mathrm{ml}$ ) from one breast was collected using an electric breastpump (Egnell Inc., Cary, IL, USA). If necessary, to assist with milk let-down, the women were encouraged to suckle their infant at the contralateral breast during collection. The milk was collected into sterile, acid-washed polypropylene containers. The milk samples were gently mixed and a portion $(25-30 \mathrm{ml})$ taken, which was subsequently freezedried. The remaining milk, which was to be used in the second part of this study, was stored at $-20^{\circ}$. The process was repeated for each woman on ten occasions over a $20 \mathrm{~d}$ period. To ensure that a representative sample was obtained, the women were advised to express samples at different times during the day (i.e. three morning, four afternoon and three evening samples) and to alternate the breast from which the milk was expressed. The ten freeze-dried portions of the milk samples collected from each woman were pooled together to give one representative sample per woman.

Chemical analysis. The samples of freeze-dried human milk were analysed in duplicate for DM, ash and total $\mathrm{N}$. The DM content of the samples was determined by drying samples in a forced-air oven at $60^{\circ}$ until a constant weight was achieved. The samples were subsequently ashed in a furnace at $500^{\circ}$ for $16 \mathrm{~h}$. Total $\mathrm{N}$ was determined by the Kjeldahl method (Association of Official Analytical Chemists, 1980).

Before amino acid analysis, the freeze-dried milk samples were defatted with light petroleum-ether (b.p. $40^{\circ}-60^{\circ}$ ) using a Soxhlet apparatus (Association of Official Analytical Chemists, 1980). The petroleum-ether extractable-fatpercentage of the milk was determined in duplicate.

Six replicates $(5-7 \mathrm{mg} /$ replicate $)$ of defatted freeze-dried human milk collected from each of the twenty women, were accurately weighed into acid-washed pyrolysed $\left(650^{\circ}\right.$, overnight) glass test-tubes $(10 \mathrm{ml})$ and $1 \mathrm{ml}$ glassdistilled $6 \mathrm{M}-\mathrm{HCl}$ (containing $10 \mathrm{~g}$ phenol/l) was added to each tube. Four of the replicates were sealed under vacuum and hydrolysed in duplicate at $110 \pm 2^{\circ}$, two for $10 \mathrm{~h}$ and two for $24 \mathrm{~h}$. An external standard $(10 \mathrm{ml} 40 \mathrm{mM}$-norleucin Code n-8513; Sigma, St Louis, MO, USA) was added to each of these hydrolysates and the two remaining replicates that had not been heated. The tubes were immediately dried down under vacuum (Automatic Speedvac Concentrator AS290, Savant Instruments Inc., Farmingdale, NY, USA) and $1 \mathrm{ml}$ loading buffer ( $0 \cdot 2 \mathrm{M}$-sodium citrate, $\mathrm{pH} 2 \cdot 2)$ was added to each tube. The two unheated replicates were deproteinized non-chemically by ultrafiltration (exclusion limit $10000 \mathrm{Da}$, Amicon Micropartition System, Amicon Division, Grace \& Co., Danver, MA, USA). The ultrafiltrates and hydrolysates were loaded onto a Pharmacia LKB - Alpha Plus Amino Acid analyser (Cambridge, Cambs., UK). The amino acids were separated by ion-exchange chromatography and detected following reaction with ninhydrin. A further six replicates of freeze-dried human milk from each woman were also analysed for cysteine and methionine after peroxyformic acid oxidation (Moore, 1963) following the same hydrolysis procedure as for the acid-hydrolysed samples. Cysteine and methionine were detected as cysteic acid and methionine sulfone respectively, after loading on to an ion-exchange HPLC system (Millipore Corporation, Waters, Chromatography Division, Milford, MA, USA), with post-column $O$-phthalaldehyde derivatization and fluorescence detection. Tryptophan, being destroyed during acid hydrolysis, was not determined. The free molecular mass pertaining to each individual amino acid was used to convert from moles to a gram weight.

Data analysis. The amino acid compositions of the hydrolysates were corrected for losses of amino acids that occurred during acid hydrolysis using equation 1 which is based on the rearrangement of a non-linear model (Darragh, 1995) that describes the simultaneous processes of amino 
acid yield and decay occurring during acid hydrolysis of a protein sample.

$$
\mathrm{A}_{\mathrm{o}}=\frac{\left[\mathrm{B}_{(\mathrm{t})}-\mathrm{B}_{\mathrm{o}}\left(\mathrm{e}^{-l \mathrm{t}}\right)\right](h-l)}{h\left(\mathrm{e}^{-l \mathrm{t}}-\mathrm{e}^{-h \mathrm{t}}\right)},
$$

where $A_{0}$ is the original amount of amino acid in protein form before hydrolysis; $\mathrm{B}_{(\mathrm{t})}$ is the amount of amino acid measured at time $\mathrm{t} ; h$ is the rate at which anino acid is liberated from its protein-bound state during acid hydrolysis, expressed as a proportion of the amount of amino acid remaining in protein form; $l$ is the rate at which an amino acid in free form is degraded or altered to an undetectable form during acid hydrolysis, expressed as a proportion of the amount of amino acid in free form during acid hydrolysis; $\mathrm{B}_{\mathrm{o}}$ is the amount of free amino acid measured in a sample before hydrolysis. The amount of each amino acid present in the milk is the sum of $A_{0}$ and $B_{0}$. The parameters $h$ and $l$ pertaining to each amino acid were derived in a previous study (Darragh, 1995). An average estimate of $A_{0}$, derived for each amino acid, using the 10 and $24 \mathrm{~h}$ hydrolysis values, was added to the average $B_{0}$ value to give the amino acid composition of the human milk samples. The amino acid $\mathrm{N}$ content of the human milk sample was determined by summation of the $\mathrm{N}$ contributed by each amino acid on a molecular mass basis.

\section{Part 2: Determination of true ileal amino acid digestibility in human milk}

\section{Methods and materials}

All aspects of the human and animal research reported in this part of the study were approved by the Massey University Human Ethics and Massey University Animal Ethics Committees respectively.

Animals and housing. Eighteen Landrace $\times$ Large White entire male piglets (average age $6 \mathrm{~d}$; mean body weight $2.3(\mathrm{SE} 0.12) \mathrm{kg}$ ) were selected at random from a group of piglets originating from nine different litters of pigs (Pig Research Unit, Massey University). The piglets were penned individually in moulded-plastic metabolism cages and were kept in a temperature-controlled room maintained at $30 \pm 1^{\circ}$ with a constant cycle of $15 \mathrm{~h}$ light and $9 \mathrm{~h}$ dark.

Diets. The three diets used included a preliminary diet, human milk and a protein-free (PF) diet. The latter diet was given to the piglets to allow determination of endogenous amino acid flows at the terminal ileum. The composition of the preliminary diet has been reported previously (Darragh et al. 1994). The composition of the PF diet (Table 1) was formulated to resemble human milk with respect to its carbohydrate, fat, vitamin and mineral components.

The preliminary diet was mixed with distilled water daily (14 g DM/100 ml water) and was kept refrigerated at $4^{\circ}$. The PF diet was also prepared daily $(14.5 \mathrm{~g} \mathrm{DM} / 100 \mathrm{ml}$ water) by mixing the non-oil fraction with warm distilled water. The oils were added and the liquid homogenized at pressures of $200 \mathrm{~kg} / \mathrm{cm}^{2}$ (stage 1) and $75 \mathrm{~kg} / \mathrm{cm}^{2}$ (stage 2). The surplus human milk from Part 1 of the study, which had been stored at $-20^{\circ}$, was thawed at $4^{\circ}$ as required. All the liquids were warmed to $35^{\circ}$ before feeding and each piglet's
Table 1. Ingredient composition of the protein-free diet used to determine endogenous amino acid flows at the terminal ileum of the 3-week-old piglet

\begin{tabular}{|c|c|}
\hline & $\mathrm{g} / \mathrm{kg}$ air-dry matter \\
\hline $\begin{array}{l}\text { Purified lactose } \\
\text { Glucose } \\
\text { Palm olein* } \\
\text { Coconut oil }^{*} \\
\text { Soyabean oil* } \\
\text { Maize oil* } \\
\text { Vitamins and minerals† } \\
\text { Emulsifier‡ }\end{array}$ & $\begin{array}{r}575 \\
87 \\
150 \\
90 \\
30 \\
30 \\
28 \\
10\end{array}$ \\
\hline \multicolumn{2}{|c|}{ 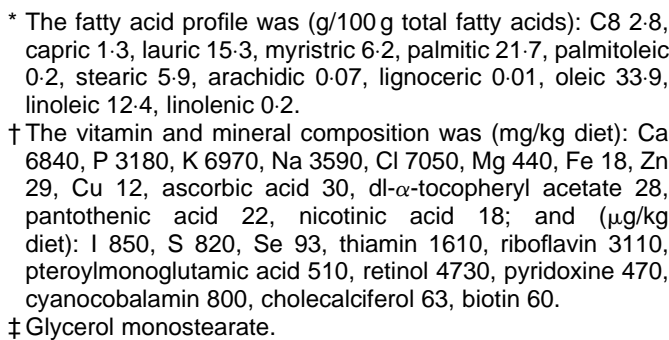 } \\
\hline
\end{tabular}

daily allocation was given in equal amounts every $2.5 \mathrm{~h}$ throughout the day, from 06.30 to 21.30 hours.

Experimental procedure. In the $9 \mathrm{~d}$ following removal from the sow and before commencement of the experimental period the piglets were trained to drink the preliminary diet from bottles with soft rubber teats attached. At each meal time the piglets were removed from their pens and individually hand-fed their diets. During each meal, the minimal spillage $(2-5 \mathrm{ml})$ which occurred was collected and meal intakes subsequently adjusted. The daily allowance for all diets was set at $42 \mathrm{~g} \mathrm{DM} / \mathrm{kg}$ body weight per $d$. This corresponded to a level of intake on a gut capacity basis $\left(0.923 \mathrm{~g} \mathrm{DM} / \mathrm{cm}^{3}\right.$ of estimated stomach volume per d) similar to that of breast-fed human infants, assuming that the piglet has a gut capacity, on a bodyweight basis, twice that of the human infant (Moughan et al. 1992a; Darragh \& Moughan, 1995). The piglets were weighed $( \pm 10 \mathrm{~g})$ on day 4 and day 8 of the preliminary period, and their feed intakes were adjusted.

At the end of the $9 \mathrm{~d}$ preliminary period each piglet was fitted with a Karaya base plate and human ostomy bag around the anal region (Darragh et al. 1994) to allow the collection of faeces, thus preventing coprophagy.

On day 1 of the $6 \mathrm{~d}$ experimental period the piglets were randomly allocated to either the human milk or PF diet (six piglets/diet) and were given a 50:50 mix of the preliminary diet and their allocated experimental diet to allow them to adapt to any variation in taste. On day 2 the piglets were weighed, the level of food intake was adjusted, and from days 2-6 of the experimental period the piglets received their allocated experimental diet. In the final $2 \mathrm{~d}$ of the experimental period fresh human milk was collected from a further ten mothers in their 10th-14th weeks of lactation, using the selection criteria and collection procedures described in Part 1. The fresh human milk was pooled and stored at $1^{\circ}$. On the penultimate and final days of the experimental period (days 5 and 6) the piglets allocated the human milk were given fresh human milk. It was 
important that the human milk fed to the piglets on the final day of the experimental period was fresh as some of the functional properties of the human milk may have been altered by freezing and storage (Garza et al. 1982). During the experimental period $\mathrm{Cr}_{2} \mathrm{O}_{3}$ was added, as an indigestible marker, to each piglet's daily allocation of human milk or $\mathrm{PF}$ diet to give a final concentration of $3 \mathrm{~g} / \mathrm{kg}$ DM. Before and during each feeding the diets were thoroughly mixed to ensure that an even distribution of the marker in the diet was maintained. On days 4 and 5 of the experimental period the meal frequency was changed to hourly feedings between 06.30 hours and 21.30 hours. It was assumed that an hourly feeding regimen would ensure a relatively constant flow of representative digesta at the end of the ileum.

On the final day of the experimental period (day 6) and beginning $10 \mathrm{~h}$ after the first feeding of the day, piglets were chosen at random to be killed for the sampling of ileal digesta. At $30 \mathrm{~min}$ after a meal, each piglet was anaesthetized with halothane gas (Fluothane, Imperial Chemical Industries Ltd., Cheshire, UK) and the abdominal cavity was opened. The $400 \mathrm{~mm}$ of ileum directly anterior to the ileo-caecal valve was isolated and dissected from the body. After removal of the ileum the piglet was killed by intracardial injection of $2 \mathrm{ml}$ sodium pentobarbitone (Anathal, $300 \mathrm{mg} / \mathrm{ml}$; Chemstock Animal Health, Christchurch, New Zealand). The external surface of the dissected ileal segment was rinsed with distilled water to remove residual blood and tissue. The contents of the section were flushed with distilled water from a plastic syringe and the digesta samples were immediately frozen. The ileal digesta samples and subsamples of the fresh human milk and PF diet were freeze-dried, finely ground and stored at $-20^{\circ}$ while awaiting chemical analysis.

Chemical analysis. The samples of freeze-dried human milk, PF diet, and the ileal digesta samples were analysed in duplicate for DM, ash and total $\mathrm{N}$ as described in Part 1. The $\mathrm{Cr}$ contents of the diets and ileal samples were also determined in duplicate by the method of Costigan \& Ellis (1987).

The amino acid compositions of duplicate freeze-dried defatted samples of the human milk and the ileal samples were determined (see Part 1) following $24 \mathrm{~h}$ acid hydrolysis. The determination of cysteic acid and methionine sulfone in the ileal digesta samples was not possible due to limited sample size. Free molecular masses of the amino acids were used to convert from moles to a gram weight.

Data analysis. The ileal flows of $\mathrm{N}$ and amino acids (AA) related to the ingestion of $1 \mathrm{~g}$ dietary DM were calculated using equation 2 (units are $\mathrm{mg} / \mathrm{g} \mathrm{DM}$ ):

$\mathrm{N}$ or $\mathrm{AA}$ flow $=\mathrm{N}$ or AA concentration in ileal digesta

$$
\times(\text { diet } \mathrm{Cr} / \text { ileal } \mathrm{Cr}) \text {. }
$$

The apparent and true ileal digestibilities of $\mathrm{N}$, amino acid $\mathrm{N}$ and the individual amino acids in the human milk were calculated using equations 3 and 4 respectively (units are $\mathrm{mg} / \mathrm{g} \mathrm{DM}$ ):

$$
\text { apparent AA digestibility (\%) }
$$

$=[(\mathrm{AA}$ intake - ileal AA flow $) / \mathrm{AA}$ intake $] \times 100$, true AA digestibility $(\%)=[(\mathrm{AA}$ intake $-($ ileal AA flow

$$
\text { - endogenous AA flow))/AA intake] } \times 100 \text {. }
$$

The amino acid compositions of ileal digesta samples from the piglets fed on either human milk or the PF diet were not corrected for amino acid losses occurring during hydrolysis because the parameters $h$ and $l$ (see equation 1) have not been determined for ileal digesta. Consequently, the digestibility values were calculated using the uncorrected amino acid composition determined after $24 \mathrm{~h}$ hydrolysis of the pooled sample of the human milk and the ileal digesta samples.

The apparent and true digestibility data for $\mathrm{N}$, amino acid $\mathrm{N}$ and the individual amino acids were analysed statistically using a one-way ANOVA (GLM procedure, Statistical Analysis Systems, 1985).

\section{Results}

For the DM, ash, N, fat and $\mathrm{Cr}$ determinations, the overall mean differences between duplicates within samples (expressed as a percentage of the mean), were $0 \cdot 6,1 \cdot 8$, $0.7,3.8$ and $6.4 \%$ respectively. For the analysis of amino acids the overall mean differences between duplicates (expressed as a percentage of the mean) were $5.4 \%$ and $2.3 \%$ for the ninhydrin detected amino acids and sulfur amino acids respectively.

\section{Part 1: Determination of the amino acid composition of mature human milk}

The chemical composition of the human milk is given in Table 2. The non-protein $\mathrm{N}$ content of the human milk determined by difference was $25.6 \%$ of the total $\mathrm{N}$. The crude protein content of the human milk, calculated by multiplying the total $\mathrm{N}$ content by the conversion factor of $6 \cdot 38$, was $11.3 \mathrm{~g} / \mathrm{l}$. Multiplying the amino acid $\mathrm{N}$ by 6.38 gave a protein content of $8.4 \mathrm{~g} / \mathrm{l}$, whereas the protein content of the milk derived by summation of the amino acids (accounting for the water of hydrolysis but excluding tryptophan) was $8.8 \mathrm{~g} / \mathrm{l}$. The parameters used to determine the amino acid composition of human milk are presented in Table 3. Estimates of $h$ and $l$ (see equation 1) were used to derive an average estimate of $A_{o}$ for each amino acid using the 10 and $24 \mathrm{~h}$ hydrolysis data. As outlined earlier, an average $B_{o}$ value was added to the $A_{o}$ value to give the final amino acid composition. The amino acid composition of human milk, corrected for losses of amino acids occurring during acid hydrolysis, can also be compared with that determined using a routine $24 \mathrm{~h}$ acid hydrolysis, in Table 3. Expression of the average amino acid composition of the human milk samples per litre, per $\mathrm{g} \mathrm{DM}$, and per $\mathrm{g}$ total $\mathrm{N}$ are given in Table 4.

\section{Part 2: Determination of the true ileal digestibility of amino acids in human milk}

One piglet (PF diet) developed diarrhoea and was removed from the study. The remaining piglets appeared healthy and consumed the diets readily. The mean growth rates during 
Table 2. The chemical $^{\star}$ composition of mature human milk $\dagger$

(Mean values with their standard errors for twenty women)

\begin{tabular}{|c|c|c|c|c|c|}
\hline & \multicolumn{3}{|c|}{$g / \mid \ddagger$} & \multicolumn{2}{|c|}{$\mathrm{g} / \mathrm{kg} \mathrm{DM}$} \\
\hline & Mean & SE & Range & Mean & SE \\
\hline Total N & 1.8 & 0.03 & $1.5-2 \cdot 0$ & 13.7 & 0.26 \\
\hline Amino acid N\$ & 1.3 & 0.02 & $1.1-1.5$ & $10 \cdot 2$ & 0.18 \\
\hline Protein $\|$ & 8.8 & 0.17 & $7.4-9.9$ & 68.5 & 1.23 \\
\hline Fat & 39.4 & 1.69 & $27 \cdot 3-55 \cdot 1$ & 304.9 & $10 \cdot 17$ \\
\hline Ash & 2.0 & 0.03 & $1 \cdot 8-2 \cdot 3$ & 15.5 & 0.31 \\
\hline
\end{tabular}

* Excluding the carbohydrate fraction which was not determined.

† Mean values for samples collected from twenty women (ten samples per woman), in their 10th-14th weeks of lactation.

$\$ 1$ litre of mature human milk contained 129 (SE 1.5) g DM.

$\S$ Calculation based on summation of the $\mathrm{N}$ contributed by each amino acid on molecular mass basis.

Rather than multiplying by a known factor (e.g. 6.38) these values were calculated based on summation of the total amino acids (both protein bound and free) determined after conversion of moles to grams using the residue molecular mass.

- Soxhlet extractable fat only.

the experimental period were 72 (SE 5) and 44 (SE 9) g/d for the piglets fed on human milk and the PF diet respectively.

The endogenous flows of amino acids at the terminal ileum for piglets fed on the PF diet (Table 5) were used to determine true ileal amino acid digestibility values (Table 6). Apparent amino acid digestibility values are also given in Table 6 . There were significant differences between apparent and true digestibility for total $\mathrm{N}$, amino acid $\mathrm{N}$ and for all of the individual amino acids except valine in human milk. The lower digestibility of total $\mathrm{N}$ compared with the digestibility of the amino acid $\mathrm{N}$ in the human milk was probably due to the lower digestibility of the non-amino acid $\mathrm{N}$ fraction in human milk. The true digestibility of the non-amino acid $\mathrm{N}$, calculated by difference, was $50 \%$.

The very low apparent digestibility for glycine in the human milk is indicative of a large excretion of endogenous glycine. The subsequent correction of this value for the endogenous flow of glycine resulted in a true digestibility more in line with the true digestibilities of the other amino acids. The essential amino acid threonine also had a low apparent digestibility, and remained the second least digestible amino acid in human milk after correction for endogenous amino acid excretion.

\section{Discussion}

In the present study, representative samples of mature human milk ( $>12$ weeks lactation) were collected from women, following recommendations for the collection and storage of human milk outlined in the literature (Department of Health and Social Security, 1981; Hamosh et al. 1984). External factors such as the maternal diet (Lönnerdal, 1986), circadian variation (Hytten, 1954) and the health of the mother (Butte et al. 1987) will affect the composition of human milk. In general, however, the protein content does not vary significantly compared with the fat, vitamin and mineral contents of human milk. This was reflected, in the present study, in the variability of the different components of human milk (Table 3) with $\mathrm{CV}$ of $19.2 \%$ and $8.2 \%$ for the fat and protein contents of the milk respectively.

Table 3. Estimates of hydrolysis and loss rates (fractions of $A$ or $B$ per $h$ respectively), $B_{0}$ values, and amino acid profiles determined after 10 and $24 \mathrm{~h}$ acid hydrolysis, which were used to calculate the amino acid composition ${ }^{\star \star}$ of mature human milk

(Mean values with their asymptotic standard error or standard error for samples of breast milk from twenty women in their 10th-14th week of lactation

\begin{tabular}{|c|c|c|c|c|c|c|c|c|c|c|c|c|}
\hline $\begin{array}{l}\text { Amino acid } \\
\text { ( } \mathrm{nmol} / \mathrm{mg} \text { defatted } \\
\text { freeze-dried matter) }\end{array}$ & $h^{*}$ & ASE & $I^{*}$ & ASE & $\mathrm{B}_{0}$ & SE & 10 h hydrolysis** & SE & $24 \mathrm{~h}$ hydrolysis ${ }^{* *}$ & SE & $\begin{array}{c}\text { Model } \\
\text { estimate } \dagger^{\star *}\end{array}$ & SE \\
\hline Aspartic acid & 0.52 & 0.107 & 0.0003 & 0.00241 & 3.75 & 0.073 & $80 \cdot 3$ & 2.48 & $77 \cdot 3$ & 1.55 & $79 \cdot 3$ & 1.7 \\
\hline Threonine & 0.28 & 0.054 & 0.0067 & 0.00318 & 5.28 & 0.086 & $40 \cdot 2$ & $2 \cdot 27$ & 39.1 & 0.70 & 44.8 & 1.36 \\
\hline Serine & 0.51 & 0.103 & 0.0023 & 0.00119 & 5.84 & 0.102 & 44.0 & 1.46 & $45 \cdot 7$ & 0.84 & $46 \cdot 7$ & 0.98 \\
\hline Glutamic acid & 0.40 & 0.074 & 0.0010 & 0.00111 & $14 \cdot 25$ & 0.174 & $125 \cdot 7$ & $2 \cdot 35$ & $133 \cdot 1$ & 1.68 & $132 \cdot 6$ & 1.90 \\
\hline Proline & 0.46 & 0.087 & 0.0002 & 0.00108 & 2.02 & 0.032 & 82.5 & 3.09 & 85.7 & 1.38 & 84.9 & 1.99 \\
\hline Glycine & 1.05 & 0.260 & 0.0013 & 0.00227 & 4.28 & $0 \cdot 101$ & 31.0 & 0.72 & 33.0 & 0.82 & $32 \cdot 8$ & 0.75 \\
\hline Alanine & 0.61 & 0.155 & 0.0008 & 0.00245 & 4.22 & 0.093 & $41 \cdot 7$ & 0.89 & 44.6 & 1.02 & $43 \cdot 8$ & 0.94 \\
\hline Valine & 0.34 & 0.073 & 0.0022 & 0.00156 & 3.99 & 0.111 & $45 \cdot 8$ & 1.53 & $50 \cdot 8$ & 1.45 & $50 \cdot 8$ & \\
\hline Isoleucine & 0.23 & 0.040 & 0.0002 & 0.00120 & 1.29 & 0.020 & 37.5 & 0.77 & $47 \cdot 3$ & 0.70 & $44 \cdot 8$ & 0.6 \\
\hline Leucine & 0.37 & 0.078 & 0.0001 & 0.00129 & 1.42 & 0.021 & $77 \cdot 1$ & 1.33 & 84.8 & $1 \cdot 30$ & $82 \cdot 2$ & $1 \cdot 2$ \\
\hline Tyrosine & 0.60 & 0.170 & 0.0004 & 0.00273 & 2.00 & 0.035 & 23.0 & 0.51 & 24.9 & 0.45 & $24 \cdot 2$ & 0.46 \\
\hline Phenylalanine & 0.31 & 0.538 & 0.0003 & 0.00037 & 3.96 & 0.062 & $26 \cdot 4$ & 1.04 & 29.5 & 0.46 & 28.7 & \\
\hline Histidine & 0.44 & 0.056 & 0.0073 & 0.00272 & 0.82 & 0.017 & $15 \cdot 6$ & 0.55 & $15 \cdot 4$ & 0.38 & 17.4 & \\
\hline Lysine & 0.31 & 0.077 & 0.0010 & 0.01121 & 1.81 & 0.031 & $45 \cdot 2$ & 1.03 & $50 \cdot 3$ & 0.88 & $49 \cdot 6$ & \\
\hline Arginine & 0.40 & 0.079 & 0.0006 & 0.00117 & 1.90 & 0.056 & $19 \cdot 6$ & 0.59 & 21.4 & 0.65 & $20 \cdot 9$ & \\
\hline Cysteine $\ddagger$ & $14 \cdot 20$ & 0.001 & 0.0088 & 0.00357 & $10 \cdot 81$ & 0.355 & $21 \cdot 1$ & 0.62 & $21 \cdot 3$ & 0.86 & 24.8 & 0 \\
\hline Methionine§ & 0.73 & 0.671 & 0 & 0.00426 & 0 & 0 & $10 \cdot 6$ & 0.26 & 11.4 & 0.37 & 11.0 & 0.2 \\
\hline
\end{tabular}

A, amount of protein-bound amino acids remaining during hydrolysis; ASE, asymptotic standard error (see Darragh et al. 1996); B, amount of amino acid in free form during hydrolysis; $\mathrm{B}_{0}$, amount of amino acid in free form in human milk; $h$, rate of amino acid hydrolysis (fractions of $A$ determined by non-linear least squares regression of multiple hydrolysis intervals); I, rate of amino acid loss (fraction of B determined by non-linear least squares regression of multiple hydrolysis intervals).

* Multiple hydrolysis intervals used in calculation of $h$ and / were $0,1,2,3,4,5,6,7,8,9,10,12,14,16,18,20,22,24,26,28,30,60$ and 120 h

** (nmol/mg defatted freeze-dried matter).

† Determined using $h, l, \mathrm{~B}_{0}$, and the 10 and $24 \mathrm{~h}$ hydrolysis profiles in a curvilinear model (see Darragh 1995).

$\ddagger$ Determined as cysteic acid. 
Table 4. The amino acid composition of mature human milk

(Mean values with their standard errors for twenty women (ten samples per woman) in their 10th-14th week of lactation)

\begin{tabular}{|c|c|c|c|c|c|c|c|}
\hline \multirow[b]{2}{*}{ Amino acid* } & \multicolumn{3}{|c|}{$\mathrm{mg} / \mathrm{l}$} & \multicolumn{2}{|c|}{$\mathrm{mg} / \mathrm{g} \mathrm{DM}$} & \multicolumn{2}{|c|}{$\mathrm{mg} / \mathrm{g}$ total $\mathrm{N}$} \\
\hline & Mean & SE & Range & Mean & SE & Mean & SE \\
\hline Aspartic acid & 1030 & 24 & $850-1220$ & 8.0 & $0 \cdot 16$ & 584 & $9 \cdot 3$ \\
\hline Threonine & 560 & 17 & $450-790$ & $4 \cdot 3$ & 0.13 & 316 & 9.1 \\
\hline Serine & 470 & 11 & $400-590$ & 3.7 & 0.07 & 268 & 4.5 \\
\hline Glutamic acid & 1900 & 32 & $1580-2120$ & $14 \cdot 8$ & 0.27 & 1083 & 11.7 \\
\hline Proline & 950 & 23 & $770-1150$ & $7 \cdot 3$ & $0 \cdot 18$ & 538 & $10 \cdot 9$ \\
\hline Glycine & 240 & 6 & $190-300$ & 1.9 & 0.04 & 136 & 1.9 \\
\hline Alanine & 380 & 9 & $310-460$ & $2 \cdot 9$ & 0.07 & 215 & $2 \cdot 3$ \\
\hline Valine & 580 & 14 & $470-650$ & 4.5 & $0 \cdot 10$ & 327 & $5 \cdot 3$ \\
\hline Isoleucine & 590 & 10 & $490-670$ & 4.5 & 0.09 & 333 & 4.4 \\
\hline Leucine & 1050 & 19 & $880-1150$ & 8.2 & 0.15 & 598 & 5.5 \\
\hline Tyrosine & 430 & 9 & $350-490$ & $3 \cdot 3$ & 0.07 & 241 & $2 \cdot 0$ \\
\hline Phenylalanine & 430 & 19 & $320-720$ & $3 \cdot 3$ & $0 \cdot 14$ & 243 & 9.1 \\
\hline Histidine & 270 & 6 & $230-330$ & $2 \cdot 1$ & 0.04 & 156 & $2 \cdot 5$ \\
\hline Lysine & 720 & 16 & $700-820$ & 5.5 & $0 \cdot 11$ & 406 & 3.8 \\
\hline Arginine & 350 & 12 & $270-460$ & $2 \cdot 7$ & 0.08 & 200 & $3 \cdot 7$ \\
\hline Cysteine† & 310 & 9 & $240-350$ & $2 \cdot 4$ & 0.06 & 173 & 3.2 \\
\hline Methionine‡ & 160 & 4 & $130-200$ & $1 \cdot 2$ & 0.03 & 90 & $1 \cdot 2$ \\
\hline Taurine & 70 & 2 & $60-90$ & 0.6 & 0.01 & 41 & 0.9 \\
\hline
\end{tabular}

* All amino acids were correlated for losses that occurred during acid hydrolysis, and were converted from moles to mg using the appropriate molecular mass including the molecular mass of the water of hydrolysis.

† Detected as cysteic acid.

$\ddagger$ Detected as methionine sulfone.

The average protein content $(8.8 \mathrm{~g} / \mathrm{l})$ of the human milk in the present study was similar to literature estimates (Lönnerdal et al. 1976; Hambraeus et al. 1978), although somewhat lower than the value of $10.7 \mathrm{~g}$ protein/l reported by the Department of Health and Social Security (1977). The non-amino acid $\mathrm{N}$ fraction $(25.5 \%)$ of the total $\mathrm{N}$ in the human milk was also similar to previously reported estimates (Lönnerdal et al. 1976; Department of Health and Social Security, 1977; Hambraeus et al. 1978).

Although precise comparison is difficult, due to the

Table 5. The mean endogenous flows of total nitrogen, amino acid nitrogen and individual amino acids at the terminal ileum of 3-week-old piglets fed on a protein-free diet

\begin{tabular}{|c|c|c|}
\hline & $\begin{array}{c}\text { Mean flow } \\
\text { (mg/g DM intake) }\end{array}$ & SE \\
\hline Total N & 1.61 & 0.250 \\
\hline Amino acid $\mathrm{N}$ & 1.03 & 0.139 \\
\hline Aspartic acid & 662 & $80 \cdot 8$ \\
\hline Threonine & 651 & 85.2 \\
\hline Serine & 545 & 77.4 \\
\hline Glutamic acid & 682 & 108.5 \\
\hline Proline & 417 & 56.8 \\
\hline Glycine & 1203 & 231.2 \\
\hline Alanine & 434 & $54 . \overline{5}$ \\
\hline Valine & 427 & 59.7 \\
\hline Methionine & 140 & $23 \cdot 4$ \\
\hline Isoleucine & 412 & $67 \cdot 7$ \\
\hline Leucine & 650 & $106 \cdot 3$ \\
\hline Tyrosine & 230 & 41.1 \\
\hline Phenylalanine & 307 & $50 \cdot 3$ \\
\hline Histidine & 205 & $36 \cdot 3$ \\
\hline Lysine & 244 & 64.6 \\
\hline Arginine & 281 & 44.4 \\
\hline
\end{tabular}

variety of collection, analysis and reporting techniques used in different studies, the average gross amino acid composition of the human milk in the present study was generally similar to the average of several literature estimates (Department of Health and Social Security, 1977; Svanberg et al. 1977; Casey \& Hambidge, 1983; Committee on Nutrition, 1985). The concentration of cysteine, however, was some $20 \%$ higher than the average literature estimate and $16 \%$ higher than the highest previously reported estimate (Department of Health and Social Security, 1977). The higher cysteine value in the present study is a result, at least in part, of the correction for losses of cysteic acid when the human milk was hydrolysed in acid before amino acid analysis. The cysteic acid in human milk has been shown to experience a loss rate, during acid hydrolysis, greater than that shown by serine (Darragh et al. 1998). Although cysteine is not generally recognized as an essential amino acid in the human adult, there is some suggestion that cysteine is essential for the human infant (Sturman et al. 1970), signifying that accurate determination of the cysteine content of human milk is necessary. To this end, correction for losses of cysteine during acid hydrolysis should be made.

The gross amino acid composition of human milk is used as a standard for determining the amino acid requirements of the infant, assuming that the amino acids in human milk are completely absorbed by the infant (FAO/WHO/ UNU, 1990). It has been suggested, however, that several of the proteins in human milk resist digestion (Hambraeus et al. 1984), as significant amounts of intact immune proteins have been found in the faeces of breast-fed infants. Van Woelderen (1987) proposed that the digestible protein in human milk could be determined by making a correction for the faecal immune proteins. The faecal method for determining amino acid digestibility, however, leads to 
Table 6. Mean apparent and true ileal digestibility of the nitrogen and amino acids in mature human milk† given to piglets

(Mean values and the overall standard error for six piglets)

\begin{tabular}{|c|c|c|c|c|}
\hline \multirow[b]{2}{*}{ Amino acid } & \multicolumn{2}{|c|}{ Digestability (\%)‡ } & \multirow[b]{2}{*}{ Overall SE } & \multirow{2}{*}{$\begin{array}{l}\text { Level of } \\
\text { significance }\end{array}$} \\
\hline & Apparent & True§ & & \\
\hline Total N & 74 & 88 & 4.5 & * \\
\hline Amino acid $\mathrm{N}$ & 84 & 95 & $2 \cdot 8$ & ** \\
\hline Aspartic acid & 86 & 95 & $2 \cdot 1$ & $* * *$ \\
\hline Threonine & 65 & 86 & 5.5 & $* * *$ \\
\hline Serine & 78 & 95 & 3.4 & $* * *$ \\
\hline Glutamic acid & 93 & 98 & 1.2 & $* \star \star *$ \\
\hline Proline & 86 & 92 & $2 \cdot 7$ & ** \\
\hline Glycine & 16 & 81 & $12 \cdot 9$ & ** \\
\hline Alanine & 81 & 95 & 3.5 & *** \\
\hline Valine & 83 & 90 & 3.6 & NS \\
\hline Methionine & 91 & 100 & 1.7 & ** \\
\hline Isoleucine & 90 & 98 & 1.7 & $* *$ \\
\hline Leucine & 92 & 99 & 1.4 & $* \star *$ \\
\hline Tyrosine & 92 & 100 & 1.7 & $* * *$ \\
\hline Phenylalanine & 82 & 93 & $3 \cdot 2$ & $* \star \star$ \\
\hline Histidine & 86 & 95 & 2.9 & * \\
\hline Lysine & 93 & 98 & 1.2 & ** \\
\hline Arginine & 89 & 101 & 2.5 & *** \\
\hline
\end{tabular}

NS, $P>0.05 ;{ }^{*} P<0.05 ;{ }^{* *} P<0.01 ;{ }^{* * *} P<0.001$

† Pooled sample of fresh human milk from ten women in their 10 th -14 th weeks of lactation.

¥Digestibility values were calculated from the dietary ratio of nutrient to $\mathrm{Cr}$, relative to the corresponding ratio in the ileal digesta.

$\$$ Corrected using endogenous amino acid flows determined after feeding piglets on a protein-free diet.

considerable overestimation of digestible protein, due to the significant microbial breakdown of protein, mainly to $\mathrm{NH}_{3}$, that occurs in the large intestine (McNeil, 1988).

An alternative approach is to determine the digestibility of the amino acids in human milk at the end of the small intestine taking into consideration the endogenous excretion of amino acids. The routine collection of ileal digesta from human infants is not feasible, however, thus dictating the use of an animal model.

The piglet would appear to be a suitable animal model for studying aspects of protein digestion in human infants. A comparative review (Moughan et al. 1992a) of the digestion of protein in milk-fed piglets and human infants highlights anatomical and physiological similarities in the digestive processes of these species, especially when comparison is made at the physiologically comparable age corresponding to peak milk output in the mother (approximately 3 weeks in the piglet and 3 months in the human infant). Furthermore, direct comparison of the digestion of a high-quality protein in human infants and piglets (Darragh \& Moughan, 1995) has demonstrated that the two species have a similar capacity to digest protein, although the comparison was limited to faecal measurements. Validation of the piglet as a model for the infant at the ileal level is more difficult. Direct comparison of the digestion of proteins at the end of the small intestine in adult human subjects and growing pigs, however, has shown similarities between the two species in their capacity to digest protein (Rowan et al. 1994). In the present study, therefore, the 3-week-old piglet was used as a suitable model for the human infant to determine the true ileal amino acid digestibility of human milk, with experimental conditions being chosen to mimic closely the feeding of milk to human infants.

The ileal amino acid flows in piglets given human milk were corrected for endogenous amino acid flows, to give true ileal digestibility values. Endogenous ileal amino acid flows can be determined after feeding an animal on a PF diet. The PF diet method has been criticized, however, as being 'unphysiological', and endogenous flows may be underestimated (Low, 1980). In the present study, the endogenous amino acid flows determined using the PF diet method were, in general, greater than those previously determined in 15-20 kg pigs (Moughan et al. 1992b; Butts et al. 1993) with the exception of glutamic acid which was lower and proline which was up to 8-fold lower when compared with previous estimates. Proline appears to be the most abundant amino acid in the endogenous excretion collected at the terminal ileum of pigs fed on PF diets (Moughan \& Schuttert, 1991; Moughan et al. 1992b; Butts et al. 1993). The abundance of proline in the digesta of pigs receiving a PF diet may be directly related to the protein status of the pig. In animals deprived of dietary protein, body protein, primarily in the form of muscle, is broken down to supply amino acids essential for metabolism. Alanine and glutamine account for more than $50 \%$ of the total $\alpha$-amino acid $\mathrm{N}$ released from muscle tissue (Rodwell, 1985). The intestinal tissue takes up large quantities of glutamine which in turn can be metabolized to proline (Rodwell, 1985), which it has been suggested (Sauer \& de Lange, 1992), leads to an increase in the excretion of both glutamine and proline into the gut lumen. When determining the endogenous excretion of amino acids using the PF diet method, the standard procedure is to feed the PF diet to the animal for $7 \mathrm{~d}$ or more before collection of digesta. In the present study the piglets were fed on the PF diet exclusively for only $4 \mathrm{~d}$. Given the low excretion of proline and glutamic acid compared with other studies, it is possible that the piglets did not receive the PF diet long enough to induce major muscle breakdown. An alternative and possibly more physiological approach to determining endogenous ileal amino acid flows, whereby ileal samples are collected from animals fed with an enzymically hydrolysed protein which is then processed to remove undigested dietary N (Butts et al. 1993), was used here in a preliminary study to determine endogenous ileal amino acid flows in the 3-week old milk-fed piglet. There was concern, however, about the validity of these flows, as difficulties were encountered in obtaining representative digesta samples. In this case, the PF diet-derived endogenous amino acid flows determined in the present study, were used to correct the ileal amino acid flows in the piglets fed on human milk.

The true ileal digestibilities of the amino acids in human milk ranged from 81 to $101 \%$. The true ileal digestibility of glycine $(81 \%)$ needs to be interpreted with caution, however, as an overestimation of the endogenous flow of glycine in animals fed on a PF diet has been reported (Moughan et al. 1992b). The apparent glycine digestibility value of $16 \%$ suggests that the endogenous excretion of glycine was considerable in the piglets fed on human milk, most probably due to conjugation of the piglets' bile acids with glycine. If the endogenous glycine flow is an overestimation, the true ileal digestibility of glycine may be 
Table 7. The profile of digestible essential amino acids in mature human milk compared with the recommended profile of amino acids required by the human infant

\begin{tabular}{lcc}
\hline Amino acid & $\begin{array}{c}\text { Digestible } \\
\text { pattern* }\end{array}$ & $\begin{array}{c}\text { Recommended } \\
\text { pattern† }\end{array}$ \\
\hline Lysine & 100 & 100 \\
Histidine & 37 & 39 \\
Isoleucine & 79 & 70 \\
Leucine & 148 & 141 \\
Methionine/cysteine & $65 \ddagger$ & 64 \\
Phenylalanine/tyrosine & 122 & 109 \\
Threonine & 65 & 65 \\
Valine & 75 & 83 \\
\hline
\end{tabular}

* Expressed relative to lysine $=100$ units and corrected based on the true ileal amino acid digestibility of human milk. Trytophan was excluded. †FAO/WHO/UNU (1985).

$\ddagger$ Assuming that the true ileal digestibility of cysteine was $100 \%$.

even lower than reported here. Jackson (1989) suggested that human milk may be an inadequate source of glycine for the infant, based on the small amount of glycine present in human milk. The results from the present study suggest that the digestible glycine content of human milk is even lower.

In addition to glycine, the amino acids threonine, proline and valine were also less digestible compared with the other amino acids in human milk. These amino acids are present in greater proportions in the immune proteins lactoferrin, secretory $\operatorname{IgA}$ and lysozyme, compared with the other proteins in human milk (Harzer \& Bindels, 1987). Their lower true digestibility may be indicative of a reduced digestibility of the immune proteins in the piglet's intestine. This has direct implications for the specification of amino acid requirements for human infants with the digestible rather than gross amino acid composition of human milk being a more appropriate base. Further, given the differences in the digestibility of individual amino acids, the digestible amino acid profile of human milk should be determined using individual amino acid digestibility values rather than a single $\mathrm{N}$ digestibility value.

The amino acid composition of human milk and the digestibility values determined in the present study were used to derive a profile of digestible amino acids for milk. The pattern of digestible amino acids (relative to lysine) was somewhat different from the pattern reported by FAO/ WHO/UNU (1985) as representative of the amino acid requirements for infants (Table 7). A combination of correction for hydrolytic losses of amino acid during acid hydrolysis and for amino acid digestibility resulted in a significant change in the proportions of the essential amino acids relative to lysine. When the digestible rather than gross amino acid composition of human milk was used as a standard, the total amount of essential amino acids relative to lysine increased. The proportions of isoleucine, leucine and the aromatic amino acids increased, while the proportions of histidine and, to a greater extent, valine decreased relative to lysine in the pattern of digestible amino acids. Higher concentrations of valine have been reported in the plasma of formula-fed infants compared with breast-fed infants (Räihä et al. 1986; Lönnerdal \& Chen, 1990). Although, this may in part be due to the higher intake of valine in formula-fed infants, the extent of the difference may be accentuated by the lower intake of digestible valine relative to lysine in breast-fed infants.

The overall true ileal digestibility of the protein $(95 \%)$ in human milk in the present study was higher than expected (Hambraeus et al. 1984; Davidson \& Lönnerdal, 1987). The piglet may have digested the human milk more efficiently than would be expected in the breast-fed infant, however, with the immune proteins in the human milk possibly being more susceptible to digestion in the piglet. Lactoferrin can exist in either an $\mathrm{Fe}$-saturated form or free of $\mathrm{Fe}$, with the Fe-saturated form being more resistant to digestion (Brock et al. 1976). Although lactoferrin in human milk is only saturated to a very limited extent (Fransson \& Lönnerdal, 1980), it has been suggested that Fe present in other compartments in the milk may be released and transferred to lactoferrin (Lönnerdal, 1985), thus increasing the resistance of lactoferrin to digestion. There is the possibility that saturation of the lactoferrin did not occur in the piglet's intestine, rendering lactoferrin more susceptible to digestion. Schmitz et al. (1991) demonstrated, however, that a significant proportion of bovine lactoferrin fed to 3-weekold piglets was detected at the end of the ileum suggesting that proteolytic resistance of the immune proteins may not be species-specific.

It is concluded that the absorbed rather than gross amino acid composition of human milk may be a more appropriate base from which to determine the amino acid requirements of infants and that when the absorbed amino acid profile of human milk is determined, the pattern of amino acid requirements is different compared with the recommended pattern. For improved accuracy in determining the digestible amino acid composition of human milk, corrections should be made for losses of amino acids which occur when human milk is hydrolysed in acid before amino acid analysis. True ileal amino acid digestibility values should be used to correct the gross amino acid composition of human milk to account for differences in digestibility among the amino acids.

\section{Acknowledgements}

The authors wish to thank the New Zealand Dairy Board for financial support. The cooperation and attention to detail shown by all the women participating in the study is also gratefully acknowledged.

\section{References}

Association of Official Analytical Chemists (1980) Official Methods of Analysis, vol. 14. Washington, DC: Association of Official Analytical Chemists.

Brock JH, Arzabe F, Lampreave F \& Pineiro A (1976) The effect of trypsin on bovine transferrin and lactoferrin. Biochimica et Biophysica Acta 446, 214-225.

Butte NF, Garza C, Burr R, Goldman AS, Kennedy K \& Kitzmiller JL (1987) Milk composition of insulin-dependent diabetic women. Journal of Pediatric Gastroenterology and Nutrition 6, 936-941.

Butts CA, Moughan PJ, Smith WC \& Carr DH (1993) Endogenous lysine and other amino acid flows at the terminal ileum of the growing pig ( $20 \mathrm{~kg}$ bodyweight): the effect of protein-free, synthetic amino acid, peptide and protein alimentation. Journal of the Science of Food and Agriculture 61, 31-40. 
Casey CE \& Hambidge KM (1983) Nutritional aspects of human lactation. In Lactation Physiology, Nutrition and Breast Feeding, pp. 85-87 [MC Neville and MR Neifert, editors]. New York, NY: Plenum Press.

Committee on Nutrition (1985) Infant nutrition and the development of gastrointestinal function. In Pediatric Nutrition Handbook, pp. 144-153 [GB Forbes and CW Woodruff, editors]. Illinois: American Academy of Pediatrics.

Costigan P \& Ellis KJ (1987) Analysis of faecal chromium derived from controlled-release marker devices. New Zealand Journal of Technology 3, 89-92.

Darragh AJ (1995) The amino acid composition of human milk towards determining the amino acid requirements of the human infant.

Darragh AJ, Cranwell PD \& Moughan PJ (1994) Absorption of lysine and methionine from the proximal colon of the piglet. British Journal of Nutrition 71, 739-752.

Darragh AJ, Garrick DG, Moughan PJ \& Hendriks WH (1996) Correction for amino acid loss during acid hydrolysis of a purified protein. Analytical Biochemistry 236, 199-207.

Darragh AJ \& Moughan PJ (1995) The three-week-old piglet as a model animal for studying protein digestion in human infants. Journal of Pediatric Gastroenterology and Nutrition 21, 387-393.

Davidson LA \& Lönnerdal B (1987) Persistence of human milk proteins in the breast-fed infant. Acta Paediatrica Scandinavica 76, 733-740.

Department of Health and Social Security (1977) The Composition of Mature Human Milk. Report on Health and Social Subjects, no. 12. London: HM Stationery Office.

Department of Health and Social Security (1981) The Collection and Storage of Human Milk. Report on Health and Social Subjects, no. 22. London: HM Stationery Office.

Dewey KG, Beaton G, Fjeld C, Lönnerdal B \& Reeds P (1996) Protein requirements of infants and children. European Journal of Clinical Nutrition 50, Suppl. 1, S119-S150.

Food and Agriculture Organization/World Health Organization/ United Nations University (1985) Energy and Protein Requirements. WHO Technical Report Series, no. 724. Geneva: World Health Organization.

Food and Agriculture Organization/World Health Organization/ United Nations University (1990) Joint FAO/WHO Expert Consultation of Protein Quality Evaluation. Rome: FAO.

Fransson G-B \& Lönnerdal B (1980) Iron in human milk. Journal of Pediatrics 96, 380-384.

Garza C, Johnson CA, Harrist R \& Nichols B (1982) Effects of methods of collection and storage on nutrients in human milk. Early Human Development 6, 295-303.

Hambraeus L, Fransson G-B \& Lönnerdal B (1984) Nutritional availability of breast milk protein. Lancet 2, 167-168.

Hambraeus L, Lönnerdal B, Forsum E \& Gebre-Medhin M (1978) Nitrogen and protein components of human milk. Acta Paediatrica Scandinavica 67, 561-565.

Hamosh M, Berkow S, Bitman J, Freed L, Happ B, Jones JB, Mehta NR, Wood DL \& Hamosh P (1984) Handling and storage of human milk specimens for research. Journal of Pediatric Gastroenterology and Nutrition 3, 284-289.

Haneberg B \& Tonder O (1973) Immunoglobulins and other serum proteins in feces from infants and children. Scandinavian Journal of Immunology 2, 375-383.

Harzer G \& Bindels JG (1987) Main compositional criteria of human milk and their implications on nutrition in early infancy. In New Aspects of Nutrition in Pregnancy, Infancy and Prematurity, pp. 83-94 [M Xanthou, editor]. Amsterdam: Elsevier Science Publishers.

Hytten FE (1954) Clinical and chemical studies in human lactation: III. Diurnal variation in major constituents of milk. British Medical Journal i, 179-182.
Jackson AA (1989) Optimizing amino acid and protein supply and utilization in the newborn. Proceedings of the Nutrition Society 48, 293-301.

Lönnerdal B (1985) Biochemistry and physiological function of human milk proteins. American Journal of Clinical Nutrition $\mathbf{4 2}$, 1299-1317.

Lönnerdal B (1986) Effects of maternal dietary intake on human milk composition. Journal of Nutrition 116, 499-513.

Lönnerdal B \& Chen C-L (1990) Effects of formula protein level and ratio on infant growth, plasma amino acids and serum trace elements. I. Cow's milk formula. Acta Paediatrica Scandinavica 79, 257-265.

Lönnerdal B, Forsum E, Gebre-Medhin M \& Hambraeus L (1976) Breast milk composition in Ethiopian and Swedish mothers. II. Lactose, nitrogen and protein content. American Journal of Clinical Nutrition 29, 1134-1141.

Low AG (1980) Nutrient absorption in pigs. Journal of the Science of Food and Agriculture 31, 1087-1130.

McNeil NI (1988) Nutritional implication of human and mammalian large intestinal function. World Review of Nutrition and Dietetics 56, 1-42.

Moore S (1963) On the determination of cystine as cysteic acid. Journal of Biological Chemistry 238, 235-237.

Moughan PJ, Birtles MJ, Cranwell PD, Smith WC \& Pedraza M (1992a) The piglet as a model animal for studying aspects of digestion and absorption in milk-fed human infants. World Review of Nutrition and Dietetics 67, 40-113.

Moughan PJ \& Schuttert G (1991) Composition of nitrogencontaining fractions in digesta from the distal ileum of pigs fed a protein-free diet. Journal of Nutrition 121, 15701574.

Moughan PJ, Schuttert G \& Leenaars M (1992b) Endogenous amino acid flow in the stomach and small intestine of the young growing pig. Journal of the Science of Food and Agriculture 60 , 437-442.

Ogra SS, Weintraub D \& Ogra PL (1977) Immunologic aspects of human colostrum and milk. III. Fate and absorption of cellular and soluble components in the gastrointestinal tract of the newborn. Journal of Immunology 119, 245-248.

Prentice A, MacCarthy A, Stirling DM, Vasquez-Valesquez L \& Ceesay SM (1989) Breast-milk IgA and lactoferrin survival in the gastrointestinal tract - a study in rural Gambian children. Acta Paediatrica Scandinavica 78, 505-512.

Räihä N, Minoli I, Moro G \& Bremer HJ (1986) Milk protein intake in the term infant. II. Effect on plasma amino acid concentrations. Acta Paediatrica Scandinavica 75, 887-892.

Robel EJ \& Crane AB (1972) An accurate method for correcting unknown amino acid losses from protein hydrolysates. Analytical Biochemistry 48, 233-246.

Rodwell VW (1985) Catabolism of the carbon skeletons of amino acids. In Harper's Review of Biochemistry, 20th ed. California: Lange Medical Publications.

Rowan AM, Moughan PJ, Wilson MN, Maher K \& Tasman-Jones C (1994) Comparison of the ileal and faecal digestibility of dietary amino acids in adult humans and evaluation of the pig as a model animal for digestion studies in man. British Journal of Nutrition 71, 29-42.

Sauer WC \& de Lange K (1992) Novel methods for determining protein and amino acid digestibilities in feedstuffs. In Modern Methods in Protein Nutrition and Metabolism, pp. 87-119 [S Nissen, editor]. New York, NY: Academic Press.

Sauer WC \& Ozimek L (1986) Digestibility of amino acids in swine: results and their practical application. A review. Livestock Production Science 15, 367-388.

Schmitz M, Ahrens F, Schön J \& Hagemeister H (1991) Amino acid absorption and its significance for protein supply. In Digestive Physiology in Pigs, pp. 85-87 [MWA Verstegen, J 
Huisman and LA Den Hartog, editors]. Wageningen: Pudoc Publishing.

Spik G, Brunet B, Mazurier-Dehaine C, Fontaine G \& Montreuil J (1982) Characterization and properties of the human and bovine lactotransferrins extracted from the faeces of newborn infants. Acta Paediatrica Scandinavica 71, 979-985.

Statistical Analysis Systems (1985) SAS User's Guide: Statistics. Cary, NC: SAS Institute Inc.

Sturman JA, Gaull G \& Räihä NCR (1970) Absence of cystathio- nase in human fetal liver: is cystine essential? Science $\mathbf{1 6 9}$, 74-76.

Svanberg U, Gebre-Medhin M, Ljungqvist B \& Olsson M (1977) Breast milk composition in Ethiopian and Swedish mothers. III. Amino acids and other nitrogenous substances. American Journal of Clinical Nutrition 30, 499-507.

van Woelderen BF (1987) Changing insights into human milk proteins: some implications. Nutrition Abstracts and Reviews (Series A) 57, 129-134. 